\title{
Spatial distribution and period of activity of the forest elephant (Loxodonta africana cyclotis) at Taï National Park, south western Côte d'Ivoire
}

\author{
Malé Roger KELY 1,2, Célestin Yao KOUAKOU*1,2, Jean-Claude Koffi BENE¹, André Djaha KOFFI 1,2, \\ Kouamé Antoine N'GUESSAN1, Manouhin Roland TIEDOUE ${ }^{3}$ \\ ${ }^{1}$ Laboratoire de Biodiversité et Gestion Durable des Ecosystèmes Tropicaux de l'UFR Environnement de l'Université \\ Jean Lorougnon Guédé, Daloa, Côte d'Ivoire, BP 150 Daloa, Côte d'Ivoire \\ ${ }^{2}$ Centre Suisse de Recherches Scientifiques en Côte d'Ivoire, 01 BP 1303 Abidjan 01, Côte d'Ivoire \\ ${ }^{3}$ Office Ivoirien des Parcs et Réserves, Côte d'Ivoire, \\ *Corresponding author: Célestin Yao KOUAKOU Email: koyacel7@yahoo.fr or celestin.kouakou@csrs.ci
}

Original submitted in on $19^{\text {th }}$ September 2018. Published online at www.m.elewa.org on $31^{\text {st }}$ January 2019

https://dx.doi.org/10.4314/jab.v133i1.6

\begin{abstract}
Objective: This study aims at determining the spatial distribution and period of activities of the forest elephant (Loxodonta africana cyclotis) at Taï National Park (TNP) to contribute to its conservation.

Methodology and results: Observations of elephants at different locations and time periods were recorded by using 87 camera traps with date and time-stamped settings. Cameras were installed following a systematic placement approach, and their geographic coordinates were recorded using a GPS. After 120 days of trapping, we observed a high concentration of activities in the southern areas of the park. For the period of activities, we noted that observations of unit individuals were recurrent during the day while those of elephant groups were more important at night.

Conclusion and application of the results: The south of the park where there is a large distribution of elephants would be more favourable to these animals. The small number and remoteness of large cities on the periphery of this area of the park could explain that pattern. The distribution and activity period information is useful for park surveillance by rangers. In addition, further studies are needed for a better explanation on the distribution pattern of elephants at TNP.
\end{abstract}

Key words: Taï National Park, elephant, camera traps, distribution, activity period.

\section{INTRODUCTION}

The Ivorian territory has been one of the most important areas for elephant populations during the past centuries within the West African region. But, the country Côte d'Ivoire-also named Ivory Coastwas the centre of an extremely lucrative ivory trade and was recognised as one of the most important carving centres (Courouble et al., 2003). The elephant, particularly sensitive to human pressure, is now confined to a few protected areas, as in the rest of West Africa (Roth et Douglas-Hamilton, 1991; Barnes, 1999; Sam et al., 2002; Hubert et al., 2010). From independence (1960) to the present day, forest cover has been greatly reduced, leading to the loss of animal habitat (Coulibaly, 1998; Koné et al., 2014; Béné et al., 2015). To offset this erosion of biodiversity, the 

africana cyclotis) at Taï National Park, south western Côte d'Ivoire.

Ivorian authorities have created a network of protected areas. Unfortunately, these protected areas, refuges for biodiversity in general, and the fauna in particular, are also subjected to aggressive human behaviour such as poaching, panning and infiltration for agricultural purposes (Coullin et Amadou, 2006). All these attacks have damaging consequences on the biodiversity of protected areas. Taï National Park (TNP) is one of the best-preserved parks in the sub-region (Schweter, 2004) and one of the few sites in Côte d'Ivoire where it is possible to say with confidence that the forest elephant (Loxodonta africana cyclotis) is present. Its presence in other parks such as Marahoué National Park, Mount Péko National Park and Mount Sangbé National Park remains hypothetical, given the pressures they face (Béné et al., 2015. Research studies have focused on TNP elephants, particularly on the

\section{METHODS}

Study site: This study took place in the Taï National Park (Figure 1), located in the south-west of Côte d'Ivoire, between the Cavally and Sassandra rivers, in a quadrilateral formed by the cities of Guiglo, Buyo, San Pédro and Taboo. It is located between $5^{\circ} 08$ 'and $6^{\circ}$ $24^{\prime}$ north latitude and $6^{\circ} 47$ 'and $7^{\circ} 25^{\prime}$ west longitude (Kouakou et al., 2009). The park is subject to an equatorial four-season transition climate, characterized by two rainy seasons and two dry seasons. There is a big rainy season from mid-March to July and a small rainy season from September to October. They are separated by a short dry season (in August) and a long dry season (November to mid-March). The average annual rainfall is about $1800 \mathrm{~mm}$. It ranges from 1700 $\mathrm{mm}$ in the north to $2200 \mathrm{~mm}$ in the south of the park (Chatelain et al., 2001). The average temperature is $24.5^{\circ} \mathrm{C}$ in the north and $26^{\circ} \mathrm{C}$ in the south (Van Rompaey, 1994). The atmospheric relative humidity is always very high, ranging from $85 \%$ to $90 \%$ under forest cover, and the air is almost saturated all night ecological niche (Alexendre, 1978), biology and habitat (Merz, 1981), group size (Merz, 1986), spatial distribution (Merz and Hoppe-Dominik, 1991, Boafo and Nandjui, 2011), human-elephant conflict (Ouattara et al., 2010) and abundance (Boafo and Nandjui, 2011). Although some of these studies have focused on the spatial distribution of elephants in TNP, this information requires updating. However, none of these studies focused on the period when the species is active. We therefore propose in this study to fill this information gap, since it is of interest to park managers in their surveillance activity. In addition, this information is essential to better understand the ecology of the species. The purpose of this study is to establish the current distribution of elephants in the PNT and to determine their periods of activity.

(Bousquet, 1978). The harmattan is irregular and very little felt; for a maximum of one or two weeks between December and January (Adou et al, 2005). The TNP belongs to the ombrophile sector (Chatelain et al., 2001). The flora is rich, with at least 1350 plant species, of which 80 are endemic and 26 are on the IUCN Red List (Chatelain et Kadjo, 2000). In terms of fauna, the 536,000 hectares park contains about 145 mammal species, corresponding to $93 \%$ of the species in this zoological group of the West Guinean forest zone; among which the Jentink's duiker (Cephalophus jentinki), the zebra duiker (Cephalophus zebra) and the Diana's cercopithecus (Cercopithecus diana diana) are endemic to the region from Sierra Leone to Taï (Bousquet, 1978). The forest elephant (Loxodonta africana cyclotis), a vulnerable species according to the IUCN Red List (IUCN, 2018) and listed in CITES Appendix I (CITES, 2017), is part of this rich faunal heritage. 


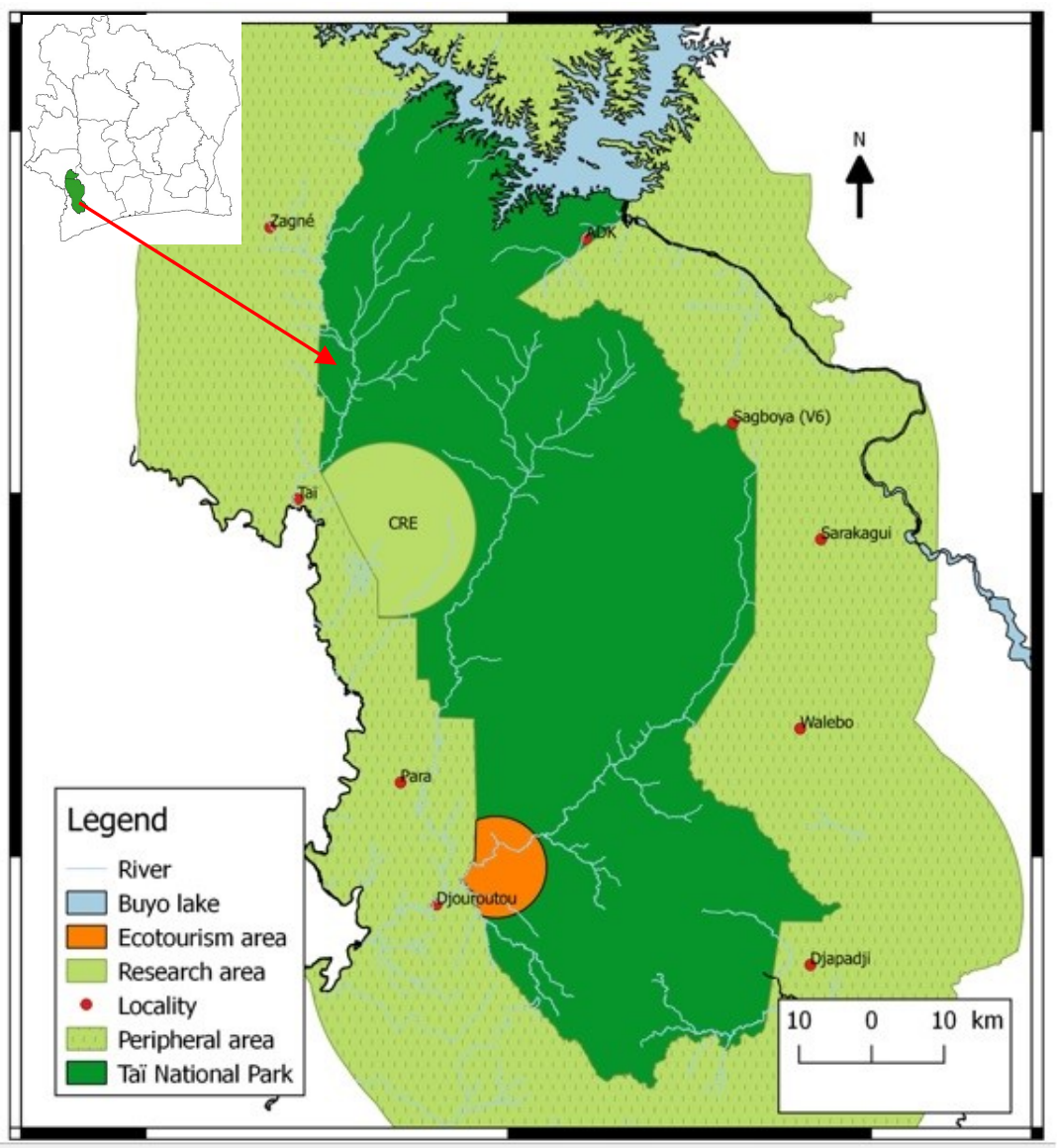

Figure 1: Study site

Data collection: Unlike conventional linear transect index counting methods in previous studies, data collection was done using Bushnell camera traps with passive infrared sensor. The installation of camera traps was done according to a systematic design in which the first point was chosen in a random way using the Qgis 2.10.1 Software; the distance between adjacent sampling points was $6 \mathrm{~km}$. This design

generated 87 camera traps' (CTs) installation points throughout the TNP (Figure 2). Trapping was done for 120 days from 09 June 2016 to 08 August 2017 and from 10 October 2017 to 09 December 2017. CTs have been set to record photos alternating with 60 seconds video clips with the date and time of recording printed on them (date and time-stamped settings). 


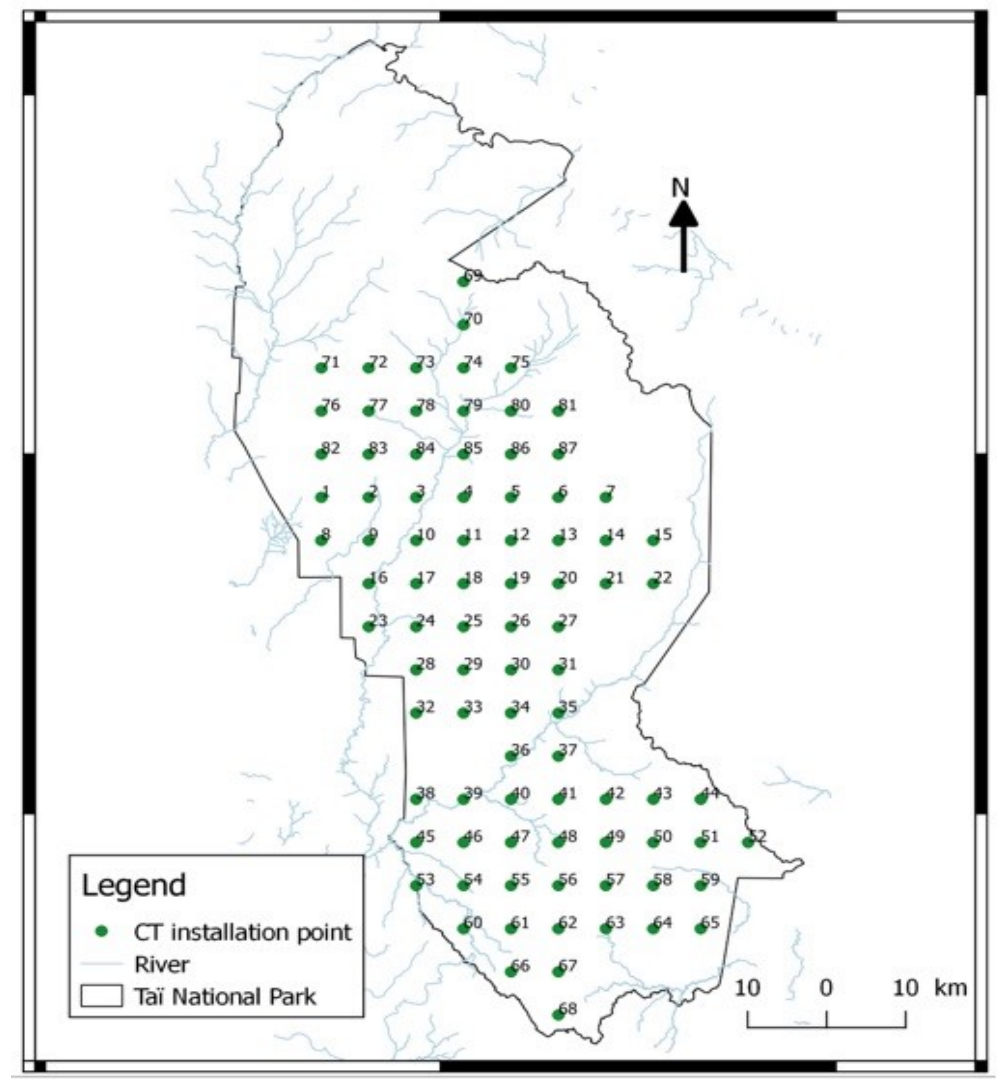

Figure 2: Trapping design for sampling elephants in Taï National Park.

CTs have been oriented to avoid having the sun in the lens. The installation position of the CT was marked using a GPS and the geographical coordinates noted on the data collection sheets. Then, the installation site of the photographic trap was characterized: canopy, characteristics of the undergrowth and type of index.

Data analysis: When analysing the data, the CT that has captured at least one elephant is rated CT positive while the CT that has not captured any elephant is rated CT negative. To analyse the influence of the type of association on the period of activity, we classify elephant captures into two categories: unit captures of individuals and group captures of individuals. For groups captures, we determined the total number of

\section{RESULTS}

Spatial distribution of elephants of TNP: We recorded 77 CTs that actually worked, of which 23 captured at least one elephant. Thus, the proportion of positive CTs over the entire PNT is $29.87 \%$ of the PPs that actually worked. For the 23 positive CTs, we recorded 37 elephant captures including 19 individual unit captures and 18 group captures. We observed individuals and the number of individuals for each age group (adult and young). From the time of each capture, we established the daily activity period of the elephants at TNP. For this purpose, the 24-hour day was divided into two periods of 12 hours each (the day from 6:00 to $17: 59$ and the night from $18: 00$ to $5: 59$ ). The notion of activity in this study refers to the period when the elephant is active, where it is moving about (Howe et al., 2017). The Qgis 2.10.1 software was used to generate elephants' distribution map. IBM SPSS Statistics version 22 software was used to perform comparison tests which were significant if the values of $P \leq 0.05$.

elephants in the different areas of the TNP, but with a high concentration in the south of the park (Figure 3). In the centre and north of the park captures were made inland (far from the periphery). In the south, however, some captures have been made towards the western limits of the park. 


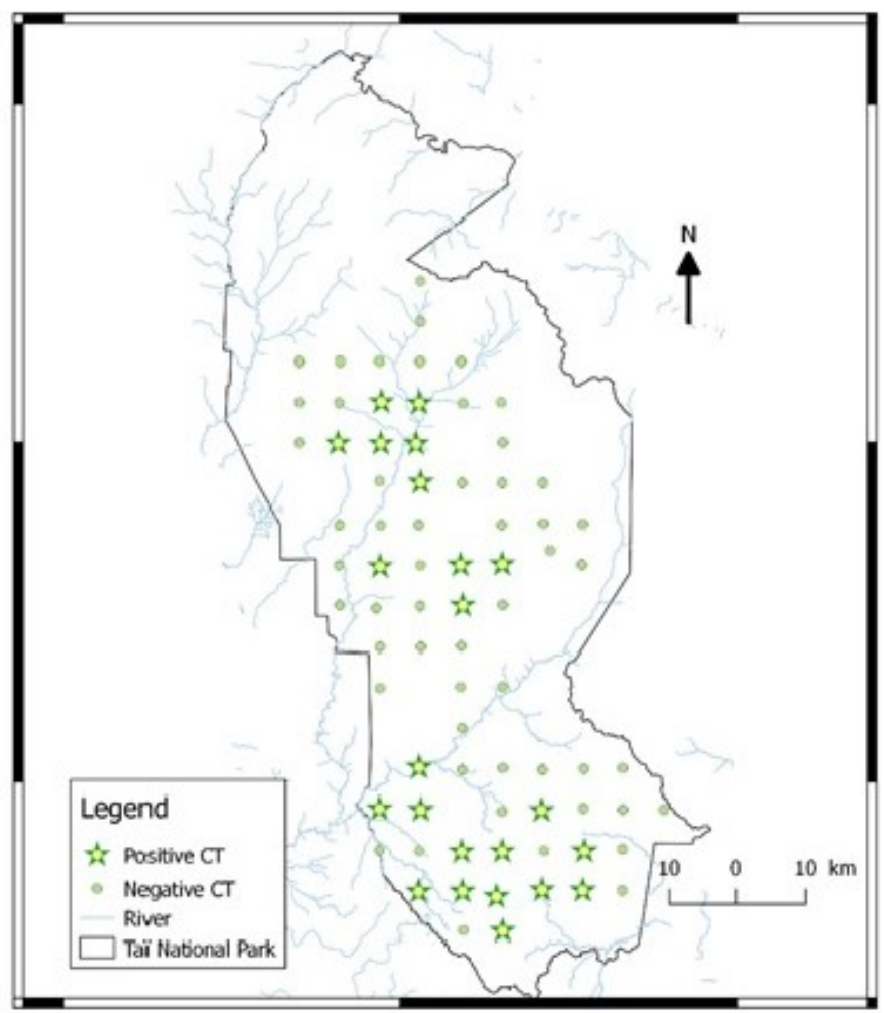

Figure 3: spatial distribution of elephants in Taï national Park

Daily activity period of TNP's elephants: Considering all captures (unit individual and group of individuals), we find that TNP elephants are active during all 24 hours of the day. A comparison of the number of captures during the two periods of the day (Figure 4) reveals that there is no significant difference between the intensity of daytime activities $(51.35 \%$ of captures and nocturnal activities (48.64\% of catches), according to the t-test, $(P$-value $=0.819)$. The influence of the type of association on the activity period is highly significant (Pearson P-value chi-square test $=0.005$ ).

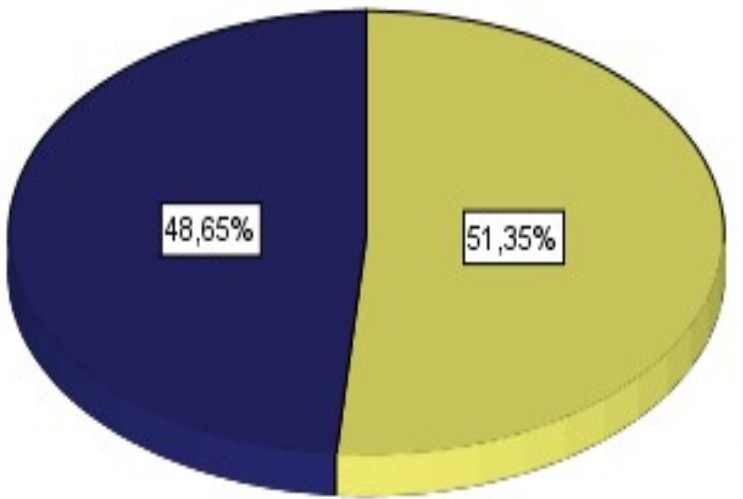

Period of activity

$\square$ Day (6H00-17H59)

Night (18H00-5H59)

Figure 4: daily activity period of all elephants at PNT

Thus, a partition of the captures in individual unit captures and in group captures, makes it possible to establish the preferred periods of activity in each category. For individuals caught alone (Figure 5), we find a highly significant difference between daytime activity (73.68\% of catches) and nocturnal activity (26.32\% of catches), (P-value $=0.002)$, according to the t-test. For groups of individuals (Figure 6), we note a highly significant difference between nocturnal activity (72.22\% of captures) and diurnal activity $(27.78 \%$ of captures), according to t-test, $(P$-value $=0.006)$. 

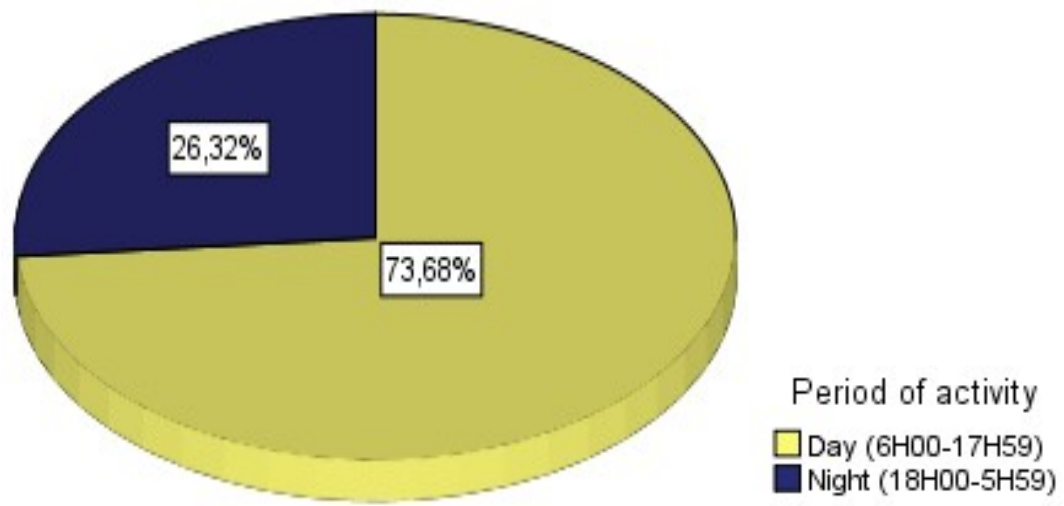

Figure 5: daily activity period of elephants detected alone at PNT

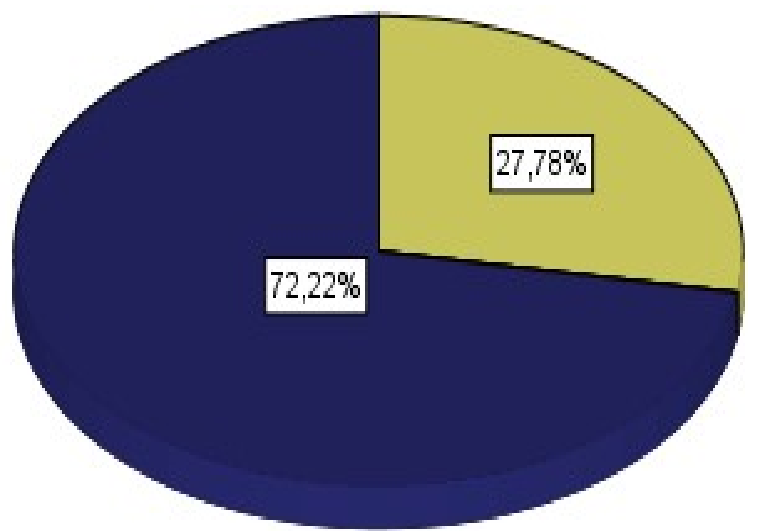

$$
\begin{aligned}
& \text { Period of activity } \\
& \square \text { Day (6H0O-17H59) } \\
& \square \text { Night (18H00-5H59) }
\end{aligned}
$$

Figure 6: period of daily activity of elephant groups at PNT

An individual captured alone during daytime activity and a group of individuals captured during nocturnal activity are illustrated with photograph 1 and photograph 2, respectively. 

africana cyclotis) at Taï National Park, south western Côte d'lvoire.

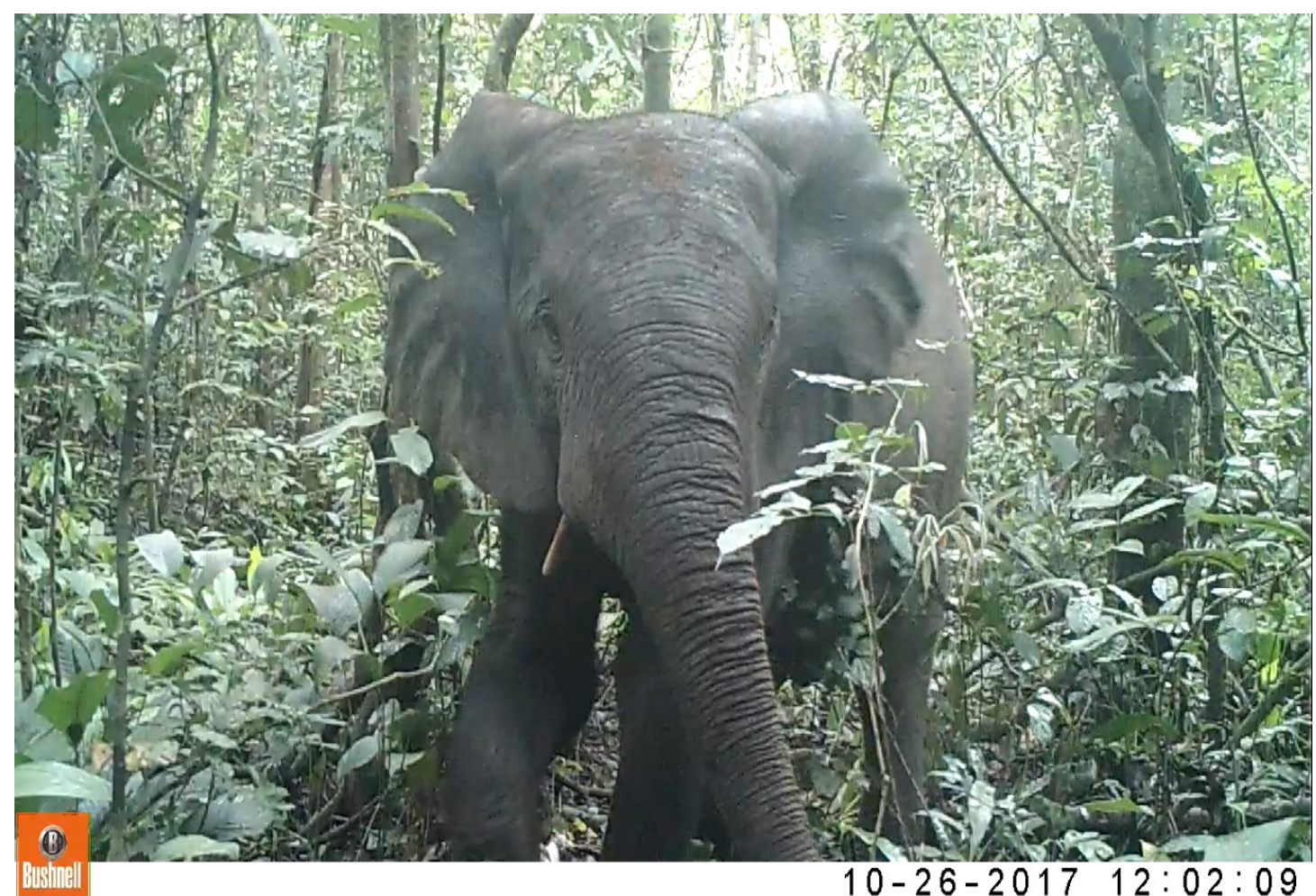

Photograph 1: Forest elephant captured alone with camera trap during daytime activity at TNP
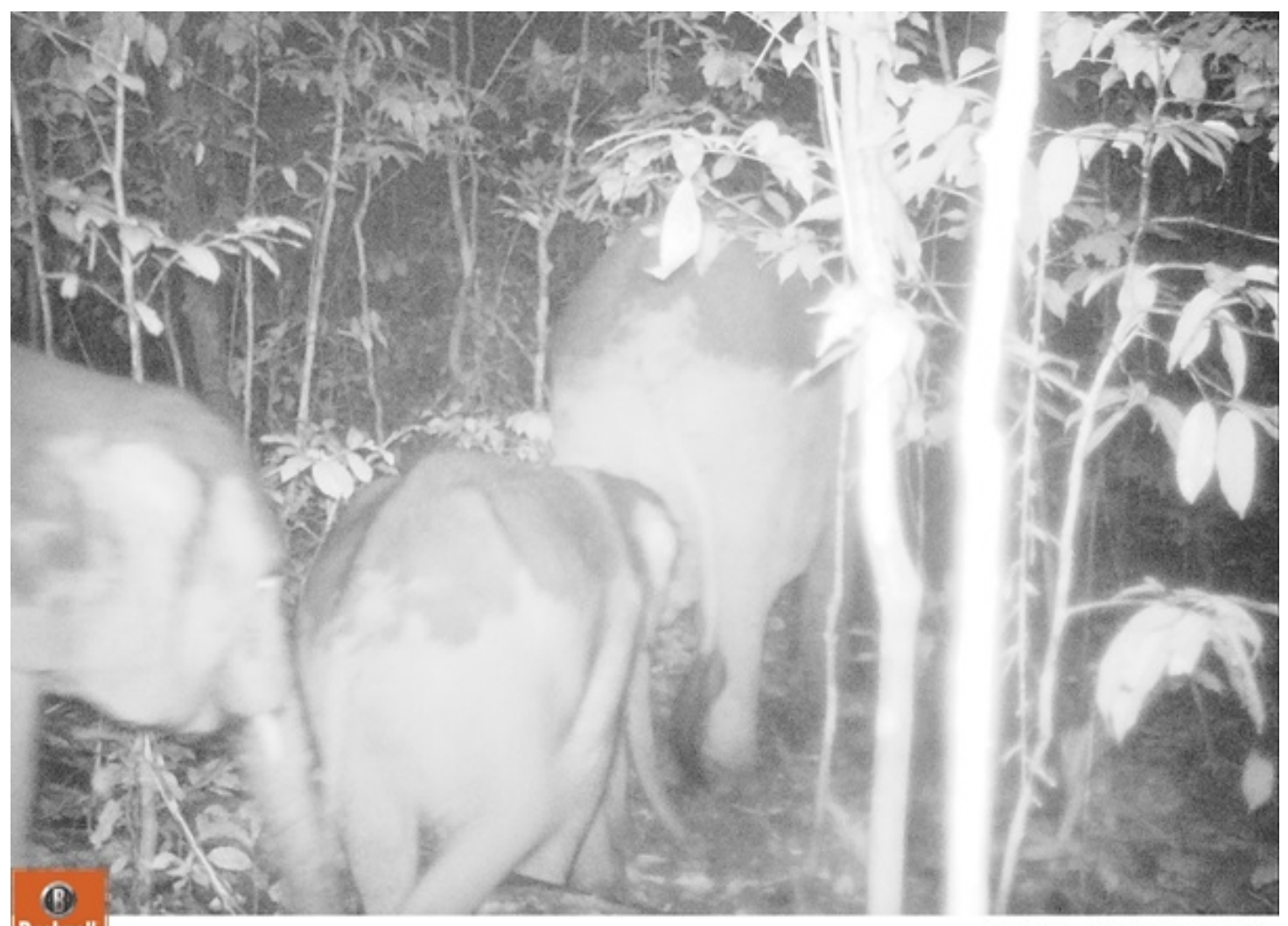

Photograph 2: Forest elephants captured with camera trap in a group during nocturnal activity at TNP 

africana cyclotis) at Taï National Park, south western Côte d'Ivoire.

\section{DISCUSSION}

This study provided updated information on two aspects of forest elephant ecology at the TNP: spatial distribution and daily activity period. The analysis of the elephant distribution map in the TNP suggests three areas of high elephant activity. This observation corroborates that of Tiedoué et al. (2016) who reported four large areas of elephant distribution at TNP. Indeed, the fourth zone located in the N'Zo reserve does not occur outside our sampling area. Among these three zones, the southern zone is the area most frequented by elephants and also, the area where we find a distribution both in the heart of the park and the periphery. This concentration of elephants in the south of the TNP could be explained by the small number and remoteness of large cities on the periphery of this area. Whereas in other areas, we encounter several large cities close to the park. The intensity and proximity of large cities could result in a density of human population which puts pressure on the park. This influence of cities on elephant distribution has been established by Barnes and Nandjui (2005) in the Ziama Reserve in Guinea. Regarding the elephant activity period at the TNP, we observed continuous elephant activity during all 24 hours of the day, with no significant difference between daytime and night time activity intensity. It has previously been shown that under normal circumstances, forest elephants are more active during the day than at night (Blake et al., 2001; Foley,

\section{CONCLUSION}

At the end of this study, the presence of elephants in the different areas of the Taï National Park was noted, but with more activity in the south of the park. Regarding the period of activity of elephants at the TNP, it was noted that the individuals detected alone were preferentially diurnal whereas the groups were more nocturnal. This study recommends that, in the anti-poaching strategy at TNP the period of activity of

\section{ACKNOWLEDGEMENTS}

This research was funded by the Volkswagen Foundation. We are very grateful to the Ivorian authorities, particularly, the Ministère de la Salubrité, de l'Environnement et du Développement Durable, and the Office Ivoirien des Parcs et Réserves, for their permission to conduct this research. We acknowledge the Centre Suisse de Recherches Scientifiques en Côte
2002. On the other hand, an equivalent level of activity between day and night would indicate the existence of anthropogenic pressures (Foley, 2002). But, this observation is only true when the captures of unitary individual and group of individuals are put together. Once partitioned, we find that individuals taken alone are more active during the day, whereas groups are more active at night. The individuals observed alone could be males, as it has been found that male elephants pursue an independent and more solitary existence with few social ties. Female members of the same family and their immature descendants live in very tight matriarchal family units (Poole, 1996). Thus, male elephants have a preferential daytime activity at TNP, whereas females have nocturnal activity. Opposition of activity peaks between males and females could have dramatic consequences on elephant breeding strategy at TNP (Ihwagi et al., 2018). In addition, the increased sightings of elephant groups at night at the TNP is the result of poaching, which is the main source of pressure for the park (UNEP, 2015). According to Ihwagi et al. (2018), elephants become more active at night than during the day to avoid poaching. They also maintain that this attitude is even more pronounced in mothers accompanied by their offspring. Like any research involving camera traps, imperfect detection remains the major limitation of our study (Burton et al., 2015).

elephants and distribution should be taken into consideration. In addition, further studies are needed for a better explanation of the distribution pattern of elephants in TNP. Further investigation of spatiotemporal analyses of camera-trap data may be key for improving the understanding of how animal population, anthropogenic activities and surveillance activities within protected areas are interacting.

d'Ivoire, the Max Planck Institute for Evolutionary Anthropology in Leipzig, and the Université Jean Lorougnon Guédé for their support during this study. We greatly acknowledge the numerous fieldwork assistants, Dr Hjalmar Kuehl and PD Dr Matthias Waltert for their help. We thank Elizabeth Kay for improving the English in this manuscript. 


\section{REFERENCES}

Adou CY, Blom EC, Dengueadhé KTS, Van Rompaey RSAR, N'Guessan EK, Wittebolle G, Bongers $F$, 2005. Diversité floristique et végétation dans le Parc National de Taï, Côte d'Ivoire. Abidjan, Tropenbos -Côte d'Ivoire série 5, 92 pp.

Alexandre D Y, 1978. Le rôle disséminateur des éléphants en forêt de Tai, Côte-d'Ivoire. Terre et vie 32:47-72.

Barnes R F W, 1999. Is there a future for elephants in West Africa? Mammal Review, 29:175 - 200.

Barnes RFW and Nandjui A, 2005. Rapport sur l'inventaire des éléphants de la forêt classée de Ziama (juillet - décembre 2004), CITES/MIKE, le centre forestier, N'zérékoré et Conservation International, $48 \mathrm{pp}$.

Béné J-C K, Daouda D, Eric N, 2015. Gestion durable de la faune et des ressources cynégétiques en Côte d'Ivoire. Rapport pour les Etats généraux de la forêt, de la faune et des ressources en eau, $100 \mathrm{pp}$.

Blake S, Douglas-Hamilton I, Karesh WB, 2001. GPS telemetry of forest elephants in central Africa: resultats of a preliminary study. African journal of ecology, 39:78-186.

Boafo Y, Nandjui A, 2011. Report on the survey of elephants in the Taï National Park in south western Côte d'Ivoire. MIKE, technical report, $35 \mathrm{pp}$.

Bousquet B, 1978. Un parc de forêt dense en Afrique: le parc national de Taì. Revue Bois et Forêts des Tropiques, 179:27-46.

Burton A C, Neilson E, Moreira D, Ladle A, Steenweg R, Fisher JT, Boutin S, 2015. Wildlife camera trapping: a review and recommendations for linking surveys to ecological processes. Journal of Applied Ecology, 52:675-685.

Chatelain C and Kadjo B, 2000. Relations faune flore dans le PNT: une étude bibliographique. In Etat des recherches en cours dans le Parc National de Taï (PNT). Sempervira 9, Abidjan: 134 - 136.

Chatelain C, Kadjo B, Koné I, Refisch J, 2001. Relations Faune-Flore dans le Parc National de Taï: une étude bibliographique. TropenbosCôte d'Ivoire, 166 pp.

CITES, 2017. Annexes I, II et III de la convention sur le commerce international des espèces de faune et de flore sauvages menacées d'extinction
(CITES), valables à compter du 02 janvier 2017, $75 \mathrm{pp}$.

Coulibaly N, 1998. Déforestation et activités agricoles en Côte d'Ivoire: recherche d'un nouvel équilibre. Thèse de doctorat, Département des sciences du bois et de la forêt Faculté de Foresterie et de Géomatique Université Laval, Québec, $131 \mathrm{pp}$.

Coullin G and Amadou B, 2006. Rapport de mission Suivi de l'état de la conservation du Parc National de Taï en Côte d'lvoire, site de Patrimoine Mondial. IUCN \& UNESCO, Switzerland \& Paris, $27 \mathrm{pp}$.

Courouble M, Hurst F, Milliken T, 2003. More Ivory than Elephants: domestic ivory markets in three West African countries. Traffic Online Report series, 8. $65 \mathrm{pp}$.

Foley LS, 2002. The influence of environmental factors and human activity on elephant distribution. Thesis submitted to the International Institute for Geo-information Science and Earth Observation in partial fulfilment of the requirements for the degree of Master of Science in Natural Resource Management, Rural Land Ecology. 47 pp.

Hibert $F$, Calenge $C$, Fritz $H$, Maillard $D$, Bouché $P$, Ipavec A, De Visscher MN, 2010. Spatial avoidance of invading pastoral cattle by wild ungulates: insights from using point process statistics. Biodiversity and Conservation, 19:2003-2024.

Howe EJ, Buckland ST, Després-Einspenner ML, Kühl HS, 2017. Distance sampling with camera traps. Methods in Ecology and Evolution, 8:1558-1565.

Ihwagia FW, Thouless C, Wanga T, Skidmorea AK, Omondi P, Douglas-Hamilton I, 2018. Nightday speed ratio of elephants as indicator of poaching levels, Ecological Indicators, 84:3844.

IUCN Red List of Threatened Species. Version 2018-1. <www.iucnredlist.orgs. Downloaded on 13 August 2018.

Koné M, Kouadio YL, Neuba DFR, Malan DF, Coulibaly L, 2014. Evolution de la couverture forestière de la Côte d'Ivoire des années 1960 au début du $21 \mathrm{e}$ siècle, International Journal of Innovation and Applied Studies, 7:782-794.

Kouakou YC, Boesch C, Kuehl H, 2009. Estimating Chimpanzee Population Size with Nest 

africana cyclotis) at Taï National Park, south western Côte d'Ivoire.

Counts: Validating Methods in Taï National Park. American Journal of Primatology, 71:447-457.

Merz G, 1981. Recherches sur la biologie de nutrition et les habitats préférés de l'éléphant de forêt, Loxodonta africana cyclotis Matschie, 1900. Mammalia, 45:299-312.

Merz G, 1986. Movement patterns and group size of the African forest elephant Loxodonta africana cyclotis in the Tai National Park, Ivory Coast. African journal of ecology, 24:133-136.

Merz G and Hoppe-Dominik B, 1991. Distribution and status of the forest elephant in the Ivory Coast, West Africa. Pachyderm, 14:22-24.

Ouattara FA, Soulemane O, Nandjui A, Tondoh EJ, 2010. Etat des maraudes et des dégâts des cultures liés aux éléphants à l'ouest du secteur de Djouroutou dans le sud-ouest du Parc National de Taï (Côte d'lvoire). Pachyderm, 47:36-44.

PNUE, 2015. Côte d'lvoire: évaluation environnementale post-conflit, rapport final, Nairobi (Kenya), 154 pp.

Poole J, 1996. L'éléphant d'Afrique. In: l'étude des éléphants, Edité par Kangwana K., 7, Nairobi (Kenya) : 1-9.

Roth $\mathrm{HH}$ and Douglas-Hamilton I, 1991. Distribution and status of elephants in West Africa (1). Mammalia, 55:489-528.

Sam MK, Haizel CA, Barnes RFW, 2002. Do cattle determine elephant distribution in the Red Volta Valley of northern Ghana. IUCN, 39.

Schweter M, 2004. Suivi de la surface de forêt du Parc National de Taï. Rapport d'activité, Mannheim (Allemagne), $26 \mathrm{pp}$.

SCOUPPE M, 2011. Composition floristique et diversité de la végétation de la zone Est du Parc National de Taï (Côte d'Ivoire). Mémoire de Master, Faculté des sciences, Université de Genève, 194 pp.

Tiedoué MR, Diarrassouba A, Tondossama A, 2016. Etat de conservation du Parc national de Taï: Résultats du suivi écologique, Phase 11. Office Ivoirien des Parcs et Réserves/Direction de Zone Sud-ouest. Soubré, Côte d'Ivoire. 31 pp.

UICN/PAPACO, 2009. Patrimoine Mondial Naturel de l'Afrique de l'Ouest: état, valeurs du label et priorités de conservation. UICN-PACOProgrammes Aires Protégées (Voir www.papaco.org), Ouagadougou (Burkina Faso), $71 \mathrm{pp}$.

Van Rompaey RSAR, 1994. Le Parc National de Taï, Côte d'Ivoire. Synthèse des connaissances. Riezebos EP, Vooren AP, Guillaumet JL (editor). Pays-Bas, Tropenbos série 8:42-50. 